\title{
ADAM SZYMAŃSKI
}

Uniwersytet Warszawski

ORCID: 0000-0002-6374-2736

\section{Differentiated integration and EU-Turkey relations: A chance for cooperation in foreign and security policies? ${ }^{1}$}

The academic debate includes the functional model of differentiated integration in the EUTurkey relations, which would mean the involvement of this state in the EU institutional framework and policies. The aim of the article is to analyse the inclusion of Turkey into the Common Foreign and Security Policy of the EU. It addresses the following questions: Is this policy a possible component of the new model of the EU-Turkey relations? What would be the potential areas of developed cooperation within this policy? Would it be possible for Turkey and the EU members to cooperate in the common neighbourhood? The author argues that the integration of Turkey into the EU foreign and security policy within the new model and as a result its cooperation with the EU countries within the common institutional framework would be possible only if the preferences and interests of the European Commission, EU members and Turkey are recognized sufficiently in the negotiated arrangement, which is currently highly problematic due to frequent contradictions between these preferences and interests, making the necessary compromise very difficult.

Keywords: European Union, Turkey, Common Foreign and Security Policy, neighbourhood, model of differentiated integration

\section{Zróżnicowana integracja i stosunki Turcji z UE. Szansa na współpracę w polityce zagranicznej i bezpieczeństwa?}

W debacie naukowej mówi się o funkcjonalnym modelu zróżnicowanej integracji w relacjach Turcji z UE, który oznaczałby włączenie tego państwa do unijnych ram instytucjonalnych i polityk. W niniejszym artykule, którego celem jest analiza inkluzji Turcji do Wspólnej Polityki Zagranicznej i Bezpieczeństwa UE, postawiono następujące pytania: Czy polityka ta

1 The article is a result of the research carried out within the project No. 2015/17/D/ HS5/00442 "Differentiated integration, Turkish accession prospects and EU geopolitics" (2016-2019), funded by the Polish National Science Center (program SONATA 9). 
jest możliwym komponentem nowego modelu stosunków Turcji z UE? Jakie byłyby potencjalne dziedziny rozwijanej współpracy w ramach tej polityki? Czy byłaby możliwa współpraca Turcji z członkami UE we wspólnym sąsiedztwie? Autor twierdzi, że włączanie Turcji do Wspólnej Polityki Zagranicznej i Bezpieczeństwa w nowym modelu i wynikająca z tego współpraca z państwami UE we wspólnych ramach instytucjonalnych byłaby możliwa pod warunkiem wystarczającego uwzględnienia w wynegocjowanym porozumieniu preferencji i interesów Komisji Europejskiej, państw UE oraz Turcji. Jest to obecnie bardzo problematyczne, a to z uwagi na częstą sprzeczność tych preferencji i interesów, co niezmiernie utrudnia osiągniecie potrzebnego kompromisu.

Słowa kluczowe: Unia Europejska, Turcja, Wspólna Polityka Zagraniczna i Bezpieczeństwa, sąsiedztwo, model zróżnicowanej integracji

\section{Introduction}

Differentiated integration in the EU has become an ever more important phenomenon (together with the process of disintegration), especially with the consolidation of the euro zone and Brexit. Although the reflection on the differentiation has been focused mostly on the relations between the EU member states (internal differentiation), some scholarly work has been already done to integrate non-EU states (including candidates to the EU membership and other EU neighbours) into the framework (external differentiation). ${ }^{2}$ It may help to map the future of EU-Turkey relations as the accession perspective becomes ever more debatable due to the changing internal dynamics both in the EU and Turkey. On one hand, during 14 years of accession negotiations only 16 out of 35 negotiation chapters were opened (and one provisionally closed), the European Parliament demanded a formal suspension of the negotiation process and the President of the European Commission ruled out "EU

2 S. Lavenex, Concentric circles or flexible 'EUropean' Integration. A typology of EU external governance relations, "Comparative European Politics" 2011, vol. 9, No. 4-5, p. 372-393; S. Gstöhl, Models of external differentiation in the EU's neighbourhood. An expanding economic community?, "Journal of European Public Policy" 2015, vol. 22, No. 6, p. 854-870; A.K. Cianciara, Differentiated integration in the European Union and its prospects in the context of enlargement and neighbourhood policies, [in:] The Euro-Atlantic system in a multi-polar world. A forecast, ed. J.M. Fiszer et al., Logos, Berlin 2015, p. 105-122; M. Müftüler-Baç, B. Luetgert, The European Union's alternative models for maximizing its integration strategy for candidates and neighbour states. A process of external differentiation, [Berlin] November 2016 (MAXCAP Working Paper, 35), available at: $<$ http://userpage.fu-berlin.de/kfgeu/maxcap/system/files/maxcap_wp_35.pdf $>$ [accessed: 21 VI 2019]; B. Lippert, The nexus between enlargement and differentiation, Instituto Affari Internazionali, [Roma] 7 II 2017, available at: <http://www.iai.it/sites/default/ files/eu60_2.pdf $>$ [accessed: 21 VI 2019]. 
membership for Turkey in the foreseeable future" due to radically deteriorating democratic and rule of law standards. ${ }^{3}$ We could also observe in 2016-2017 worsening relations with EU countries which oppose more and more openly the Turkish accession: first of all, Germany, Austria and the Netherlands. ${ }^{4}$ On the other hand, the EU has been successfully cooperating with Turkey on the migration issue, while launching a series of sectoral high-level dialogues. ${ }^{5}$ In December 2016 the European Commission also proposed to start negotiations on an updated and enhanced customs union, but the process has been blocked by some member states in the Council, in particular Germany due to the deterioration of democratic rules after the failed coup in July $2016 .{ }^{6}$ With both growing politicization and interdependence between the EU and Turkey in terms of economic and security interests, a differentiated integration model provides for an opportunity to move forward.

On the basis of the already existing forms of differentiated integration in the EU-Turkey relations linked to the customs union, the extended model of differentiated integration has begun to be proposed in the academic debate by such authors as Sinan Ülgen, Sieglinde Gstöhl and first of all Meltem Müftüler-Baç. ${ }^{7}$ This extended model must provide for more flexible

3 European Parliament resolution of 6 VII 2017 on the 2016 Commission Report on Turkey (2016/2308(INI)), P8_TA-PROV(2017)0306; President Jean-Claude Juncker's state of the Union address 2017, "European Commission" [online], 13 IX 2017 [accessed: 21 VI 2019], available at: <http://europa.eu/rapid/press-release_SPEECH-17-3165_en.htm>.

4 See e.g. S. Güsten, C. von Salzen, Fall Yücel hat für uns besondere Dringlichkeit. "Der Tagesspiegel" [online], 16 II 2018 [accessed: 21 VI 2019], available at: <https://www.tagesspiegel.de/politik/-deutschland-und-die-tuerkei-fall-yuecel-hat-fuer-uns-besondere-dringlichkeit/20968418.html>.

5 A.K. Cianciara, A. Szymański, Differentiated integration. Towards a new model of European Union-Turkey relations?, "Turkish Studies” [online], 22 V 2019 [accessed: 21 VI 2019], available at: $<$ https://doi.org/10.1080/14683849.2019.1618190>.

6 K. Kirişci, O. Bülbül, The EU and Turkey need each other. Could upgrading the customs union be the key?, "Brookings" [online], 29 VIII 2017 [accessed: 21 VI 2019], available at: $<$ https://www.brookings.edu/blog/order-from-chaos/2017/08/29/the-eu-and-turkey-need-each-other-could-upgrading-the-customs-union-be-the-key>; C. Özcan, Merkel conveys Germany's veto on Customs Union update with Turkey to Juncker, "Hurriyet Daily News" [online], 31 VIII 2017 [accessed: 21 VI 2019], available at: <http://www.hurriyetdailynews.com/merkel-conveys-germanys-veto-on-customs-union-update-with-turkey-to-juncker-117422>.

7 S. Ülgen, Avoiding a divorce. A virtual EU membership for Turkey, "Carnegie Europe" [online], 5 XII 2012 [accessed: 21 VI 2019], available at: $<$ http://carnegieeurope. eu/2012/12/05/avoiding-divorce-virtual-eu-membership-for-turkey-pub-50218>; S. Gstöhl, Models..., p. 854-870; M. Müftüler-Baç, Turkey's future with the European Union. Alternative model of differentiated integration, "Turkish Studies" 2017, vol. 18, No. 3, p. 416-438. 
and functional institutional framework of the enlargement policy. This kind of framework requires going beyond the classical model of membership and building a more complex concept of temporary, kind of virtual membership ${ }^{8}$, following the idea of gradual, partial membership ${ }^{9}$, with a dynamic integration method to gain the formal (full) membership after the ratification of the accession treaty in the long run. This means a formal continuation of the accession talks which are not very likely to continue but at the same time difficult to stop. Such a flexible and functional model would also mean, in more concrete terms, the involvement of Turkey into the institutional framework and decision-making system of the EU as well as clusters of the EU policies, leading to a marked improvement over the status quo in the EU-Turkey relations.

The aim of the article is to analyse the possibility of the inclusion of Turkey into one of the EU policies, which is usually mentioned both by scholars and practitioners as a possible area of integration of Turkey with the EU, i.e. the Common Foreign and Security Policy (CFSP). The text goes beyond placing the debate about the cooperation of Turkey and the EU in foreign and security policy in the context of the differentiated integration. It takes a step further and critically reflects on specific implementation challenges with regard to EU-Turkey cooperation in this field as practical limitations associated with moving from accession to differentiation paradigm have been until now overlooked in the literature.

A particular focus will be put on the institutional aspects as well as the policy towards neighbours of Turkey and the EU. The article addresses the following questions: Is the foreign and security policy a possible component of a new model of the EU-Turkey relations which can be implemented within the process of differentiated integration? What would be the potential areas of developed cooperation within this policy, in the case of implementation of the model? Would it be possible for the EU members and Turkey to cooperate together in the common neighbourhood? The author would like to verify the hypothesis that the integration of Turkey into CFSP within the model of differentiated integration and as a result the cooperation of EU countries and the Turkish partner within the common institutional framework would be

8 S. Ülgen, Avoiding a divorce...

9 C. Karakas, Gradual integration. An attractive alternative integration process for Turkey and the EU, "European Foreign Affairs Review" 2006, vol. 11, No. 3, p. 311-331; idem, EU-Turkey. Integration without full membership or membership without full integration? A conceptual framework for accession alternatives, "Journal of Common Market Studies" 2013, vol. 51, No. 6, p. 1057-1073. 
possible under the condition of sufficient recognition of the preferences and interests of the major actors in this field, namely the European Commission, EU members states and Turkey itself, within the negotiated arrangement.

The text is based on the international theory of cooperation. It is a useful tool (unused in the context of EU-Turkey relations before) to assess the possibility of inclusion of Turkey into CFSP and cooperation within this policy, while using the empirical data - both primary sources (in-depth interviews with Turkish and EU experts) and various studies to date. It will be based on a qualitative approach.

The article consists of three parts. The first one will outline the conditions of international cooperation. The second chapter will be a short reminder of the current involvement of Turkey into the CFSP as well as a review of ideas of further inclusion to this EU policy - both within the old alternatives to the EU membership of Turkey and new models of the EU-Turkey relations in the context of differentiated integration. The last part includes a critical assessment of the possibility of inclusion of Turkey into the CFSP within a possible extended model of differentiated integration.

\section{Theoretical framework: conditions of international cooperation}

The classical literature concerning the international theory of cooperation includes first of all the definition of international cooperation and conditions under which this cooperation is likely to emerge. ${ }^{10}$ The second aspect will be useful for the purpose of this article. The integration with the EU and cooperation with EU members are obviously two different issues but they are related to each other in the Turkish case. This list of conditions of effective international cooperation can help in this context in assessment of possibility of the development of cooperation between the EU and Turkey after establishing the common framework in foreign policy, assuming that the development of cooperation - reflected e.g. in increasing number of common undertakings in the neighbourhood - would prove the real and effective inclusion of Turkey into CFSP.

Helen Milner writes about six conditions (hypotheses) of cooperation which are pointed in the literature in the 1990s. It is, firstly, about gains of international actors - absolute or relative as well as about the strategy

10 H. Milner, International theories of cooperation among nations. Strengths and weaknesses, "World Politics" 1992, vol. 44, No. 3, p. 467. 
of reciprocity which may be conductive to cooperation. The second issue is the number of actors. It can be said (with reservations) that the higher number of players, the less possible is the effective cooperation. According to the (third) iteration hypotheses, state's willingness to cooperate is influenced by whether they believe they will continue to interact indefinitely. The fourth condition is included in the international regimes hypotheses which says about facilitating international cooperation thanks to the reduction of transaction and information costs by the international regimes. The fifth condition concerns the existence of epistemic communities of actors who share common beliefs, values, approaches, understanding of problems and their solutions. This condition is close to the fourth one. Both international regime and epistemic community reduce uncertainty in relations. The difference lies in the type of the provided information - while the international regime gathers data on preferences and compliance of other partners, the epistemic community provides expert information which enables coordination of states' expectations. The sixth one refers to the power asymmetries hypothesis according to which actors with different potential and capabilities may develop cooperation. Milner proves that these hypotheses have one major weakness, namely that the conditions of the emerging of cooperation depend often on the domestic politics and factors. ${ }^{11}$

Many of these conditions, including the role of domestic politics, were repeated later by other authors. A reputation of potential cooperation partners and trust between them are mentioned additionally as important factors connected with the reciprocity. ${ }^{12}$ These conditions will be indicated in the text as favourable or unfavourable factors for the effective implementation of the model of EU-Turkey relations in the field of foreign and security policy.

\section{Turkey and CFSP}

It is necessary to outline the current involvement of Turkey in the CFSP as well as ideas about further inclusion of the candidate country to this area of EU activities - within old alternative concepts to the EU membership and new proposals presented in the context of differentiated integration.

11 Ibidem, p. 466-496.

12 X. Dai, D. Snidal, M. Sampson, International cooperation theory and international institutions, [in:] Oxford research encyclopedia of international studies, Oxford University Press, Oxford, March 2010. 


\section{State to date}

Turkey has been already included to some extent into the CFSP as well as the Common Security and Defence Policy (CSDP). It is one of the chapters within the accession negotiations (chapter 31). According to the European Commission's report on Turkish progress towards accession this candidate is "moderately prepared in the area of foreign, security and defence policy."13 It takes part in the EU-led missions, although mainly through the NATO-EU cooperation scheme. As Müftüler-Baç rightly noticed, "Turkey participated in nine out of 30 only EU-led operations with significant participation in the Balkans, making its contribution one of the largest after France, Germany and the UK in general." ${ }^{\prime 14}$ In 2018 it still took part in the military crisis management operation EUFOR "Althea" in Bosnia and Herzegovina. After the coup attempt in July 2016 it suspended its participation in EM Ukraine and EULEX Kosovo but it declares further involvement in these missions. ${ }^{15}$

Turkey takes part occasionally in the informal meetings of EU foreign ministers - Gymnich. ${ }^{16}$ There is also a formal CSDP Dialogue Instrument between Turkey and the EU (including regular meetings between EU's High Representative for Foreign Affairs and Security Policy and the Turkish Foreign Minister). The political dialogue on foreign and security policy issues is held at many levels. For instance, when it comes to the year 2017, a high-level political dialogue took place on 25 July. Foreign policy issues belong to main part of the meeting agenda. There have been constant ministerial level contacts. The conflict in Syria was the most important topic in 2017. Political Directors' meetings took place in January and June 2017. Discussions focussed mainly on the Middle East (Syria, Iraq, Libya, Qatar, Middle-East Peace Process) and on key international developments. The EU-Turkey dialogue on counter-terrorism took place in Ankara in November 2017. ${ }^{17}$

However, there is also a problem of involvement of Turkey in the CFSP, indicated by the European Commission. It is about insufficient "alignment with EU declarations and Council decisions on common foreign and security

13 Turkey 2018 Report. Strasbourg, 18 IV 2018, SWD(2018) 153 final, p. 96, available at: $<$ https://ec.europa.eu/neighbourhood-enlargement/sites/near/files/20180417-turkey-report.pdf $>$ [accessed: 21 VI 2019].

14 M. Müftüler-Baç, Turkey's future..., p. 428.

15 Turkey 2018..., p. 98.

16 S. Aydın-Düzgit, N. Tocci, Turkey and the European Union, Palgrave Macmillan, London-New York 2015, p. 64.

17 Turkey 2018..., p. 96. 
policy." ${ }^{18}$ Nevertheless Turkey - with its geopolitical position as well as economic potential, civilian human resources and military capabilities - has been still recognized as a valuable partner for the EU in terms of contacts with the neighbouring regions - the Middle East, South Caucasus and the Balkans. ${ }^{19}$ It was a reason why foreign and security policy was a part of the so-called Positive Agenda - Commission's initiative of 2012 to reinvigorate the EU relations with Turkey and the pre-accession process. ${ }^{20}$

\section{Concepts of inclusion}

The CFSP was often presented as a substantial component of proposals of alternative models of the EU-Turkey relations. ${ }^{21}$ The most popular proposal in the first decade of the $21^{\text {st }}$ century was the privileged partnership as the third way between the full membership and association status of Turkey. One of its elements was the inclusion in initiatives implemented as part of CFSP, although without the decision-making competences. The supporters of this concept (including French and Austrian as well as CDU and CSU politicians) proposed the participation of Turkey in regularly held consultations on preparing common positions and activities, on formulating common strategies, and in the meetings of the EU foreign ministers on subjects of interest to Turkey (relations with the Middle East, South Caucasus and Central Asia). ${ }^{22}$ There was a talk in this context about the special CFSP dialogue mechanism on the ministerial level - in addition to the political dialogue (something which has currently become a reality). The stage before the inclusion to the CFSP was to be the association with this policy. Turkey would take part in meetings of foreign ministers as well as the Political and Security Committee and it would be consulted regularly beforehand. According to their proposal the cooperation within the framework of the then European Security and Defence Policy

18 Ibidem.

19 M. Emerson, N. Tocci, Turkey as a bridgehead and spearhead. Integrating EU and Turkish foreign policy, Centre for European Policy Studies, August 2004 (EU-Turkey Working Papers, 1), p. 33.

20 Positive EU-Turkey agenda launched in Ankara, Brussels, 17 V 2012, available at: $<$ http://europa.eu/rapid/press-release_MEMO-12-359_en.htm> [accessed: 21 VI 2019].

21 C. Atilgan, D. Klein, EU integration models beyond full membership, Konrad Adenauer Stiftung, Berlin 2006 (Working Paper, 158), available at: <http://www.kas.de/wf/doc/ kas_8414-544-2-30.pdf?061221153540> [accessed: 21 VI 2019]; A. Szymański, Alternatives to EU membership. The case of Turkey, "The Polish Quarterly of International Affairs" 2007, No. 4, p. 55-72.

22 Ibidem, p. 57-60. 
(such as participation in its institutions or in the setting up of battle groups) could be strengthened as well. Turkey could be involved in such areas of EU activities as: humanitarian and development policy, promotion of democracy as well as conflict prevention and participation in EUFOR operations. ${ }^{23}$ Many of these aspects have been actually implemented.

The CFSP was proposed also in all other main concepts in the past, without elaborating on details. The Extended Association Membership (EAM) included first of all the proposals concerning EU economic policies because it was aimed at extension of framework of the European Economic Area (EEA). However, Wolfgang Quaisser and Steven Wood proposed the EAM Council with the participation of foreign ministers of EU and Turkey (following the pattern of EEA Council) to consult the foreign affairs issues. Moreover, the intense cooperation within the European Security and Defence Policy was one of proposals going beyond the institution framework of the EEA. A new Security and Defence Policy Council would serve the coordination of security policies of the EU member states and Turkey. ${ }^{24}$

The concept of gradual membership was about the gradual integration of Turkey into the selected EU policies - starting from the less common policies such as the CFSP through Justice and Home Affairs (currently Area of Freedom, Security and Justice) to internal market. There were criteria to be fulfilled to reach the next integration stage after the decision made by EU member states. Once Turkey was integrated in a policy area, it would acquire sectoral decision-making rights but no veto. ${ }^{25}$

The increasingly advanced process of the differentiated (dis)integration in the EU is accompanied by proposals of new formats of the EU-Turkey relations - designed particularly for Turkey or for other countries such as United Kingdom (after Brexit) but with the possibility of implementation also in the Turkish case. The foreign and security policy area has also been part of these new models. When it comes to the aforementioned model of the EUTurkey relations, Müftüler-Baç proposes in the area of the foreign and security

23 K.-T. zu Guttenberg, Die Beziehungen zwischen der Türkei und der EU - eine "Privilegierte Partnerschaft", Hanns-Seidel-Stiftung, Akademie für Politik und Zeitgeschehen, München 2004 (Aktuelle Analysen, 33), available at: <https://www.hss.de/fileadmin/migration/downloads/aa33_internet.pdf $>$ [accessed: 21 VI 2019].

24 W. Quaisser, S. Wood, EU member Turkey? Preconditions, consequences and integration alternatives, Forost, [München] October 2004 (Forost Arbeitspapier, 25), p. 53-55, available at: <http://edoc.vifapol.de/opus/volltexte/2008/806/pdf/forost_Arbeitspapier_ 25.pdf> [accessed: 21 VI 2019].

25 C. Karakas, Gradual integration..., p. 324-328. 
policy the participation of Turkey in permanent structure cooperation (PESCO). It is "a Treaty-based framework and process to deepen defence cooperation amongst EU Member States who are capable and willing to do so." ${ }^{26}$ PESCO, though with binding commitments, is flexible in terms of choice of projects by participants, decision making process (remaining in the hands of participating member states) and recognition of the specific character of the security and defence policy of the involved countries. From the Turkish perspective, it is important to mention that there are proposals to allow non-EU states to take part in certain PESCO projects. ${ }^{27}$ The Turkish scholar writes also about the possible participation of Turkey in foreign and security-related Council meetings as well as working groups within the Council. In her opinion the further steps in security integration of Turkey with the EU could be then the involvement in the European Defence Agency (EDA) as well as a seat at the table of the Military and Political Committees. ${ }^{28}$

The integration with the EU within the CFSP is also part of the concept of the continental partnership proposed mainly for the UK after Brexit but with the possible application in Turkey. The partnership should involve a close cooperation on foreign policy, security and defence matters. According to the authors of the concept it is indispensable due to many international challenges and security threats which require cooperation with the EU members - possible within the proposed partnership. ${ }^{29}$ Both the UK and Turkey are NATO members who have interests in close cooperation with the EU in the foreign and security policy. However, it is questionable to talk about following the future model of EU-UK relations in this area by Turkey. These states have a different political situation and the strategic culture in the foreign policy as well as opposing general objectives regarding relations with the EU ("out" vs "in" objective) and different state of relations with the EU to date, including the analysed policy. Moreover, it is not certain, if the participation of the UK in the CFSP as the third country is the scenario to be implemented

26 See factsheet: Permanent Structured Cooperation - PESCO, 5 III 2018, available at: $<\mathrm{https}$ ://eeas.europa.eu/sites/eeas/files/pesco_factsheet_09-03-2018_0.pdf $>$.

27 J. Barigazzi, Doors open to keep Britain in EU (security), "Politico" [online], 5 V 2018 [accessed: 21 VI 2019], available at: <https://www.politico.eu/article/europe-defensepesco-military-extend-cooperation-to-non-eu-countries-say-benelux-countries $>$.

28 M. Müftüler-Baç, Turkey's future..., p. 428-429.

29 J. Pisani-Ferry, N. Röttgen, A. Sapir, P. Tucker, G. B. Wolff, Europe after Brexit. A proposal for a continental partnership, "Bruegel" [online], 29 VIII 2016 [accessed: 21 VI 2019], available at: $<$ http://bruegel.org/2016/08/europe-after-brexit-a-proposal-for-a-continental-partnership $>$. 
in the future (other possible options are the main cooperation through NATO or a kind of new bilateralism basing on close ties with France).$^{30}$

\section{Question of implementation}

Assuming that the EU member states accept generally the extended model of differentiated integration for the EU-Turkey relations, other key question appear. Can the proposal concerning the foreign and security policy field be effectively applied? Can Turkey be a part of CFSP and as a result develop cooperation in foreign and security field with the EU members within the common framework, first of all in relation with neighbouring regions? The author of the article will critically discuss specific implementation challenges in this context, following only a few scholars who recognize the problems. ${ }^{31}$

\section{Promising aspects}

There are currently several promising aspects that enable to think realistically about the possibility of implementation of the proposal concerning the increasing participation of Turkey in the CFSP. First, the proposed models include the CFSP because the further involvement of Turkey into this policy would serve the interests of both sides, first of all with regard to the policy towards the Middle East, South Caucasus or the Mediterranean region. There are many political, security and economic challenges for the EU and Turkey in these regions nowadays: destabilization of the Middle East after the Arab Spring - increasing number of conflicts and tensions - domestic and regional, rising terrorism threat, problems with regime of non-proliferation of weapons of mass destruction, economic instability and the migration issue. It is a strong incentive to develop cooperation between the EU and Turkey to face together the common challenges. ${ }^{32}$ The further inclusion of Turkey into CFSP

30 B. Martill, M. Sus, Post-Brexit EU/UK security cooperation: NATO, CSDP+, or "French connection”?, "The British Journal of Politics and International Relations" 2018, vol. 20, No. 4, p. 846-863. Interestingly, although the solution for the EU-UK relations in the foreign and security field is difficult to apply directly in the Turkish case, this component of new models of relations with the EU may be similar at the end of the day.

31 E. Turhan, Thinking out of the accession box. The potential and limitations of internal and external differentiated integration between Turkey and the EU, Centre international de formation européenne, 3 VII 2017 (CIFE Policy Paper, 58), available at: <https:// www.cife.eu/Ressources/FCK/files/publications/policy\%20paper/CIFE_Policy_Paper_58_Thinking_out_of_The_Accession_Box_EU_Turkey_Ebru_Turhan_2017_1. pdf $>$ [accessed: 21 VI $201 \overline{9}$ ].

32 M. Müftüler-Baç, Turkey's future..., p. 429. 
seems to be a strong facilitating factor in this context. It is about the gains (rather relative than absolute) as well as long perspective of cooperation due to complexity of challenges that belong to the main conditions of development of international cooperation.

Secondly, there is a solid basis for further inclusion of Turkey in CFSP, confirmed e.g. by the European Commission's progress reports..$^{33}$ The proposed model of extended differentiated integration for the EU-Turkey relations gives the opportunity to make progress in this direction. It is so first of all because it can remove some obstacles to date to the development of cooperation between the EU and Turkey in the foreign and security field. There are a few conditions of development of cooperation in the field between the EU and Turkey, particularly with reference to the common neighbourhood. The general one (i.e. the one which does not concern foreign policy directly) is about keeping the EU membership prospect (even if it is a very long-term project). ${ }^{34}$ Turkey was suspicious of the development of the cooperation e.g. within the Positive Agenda in the foreign policy field because some Turkish authorities perceived this Commission's proposal as another alternative to the EU membership, despite the EU assurance that this was not the Commission's intention. ${ }^{35}$ The extended model of differentiated integration applied for the EU-Turkey relations would not exclude the formal membership in the long run.

There are also a few direct conditions for the development of cooperation between the EU and Turkey in foreign and security field, particularly in the common neighbourhood, i.e. defining foreign policy objectives and priorities by the EU states and Turkey, articulating mutual expectations and meeting them as well as presenting concrete proposals of cooperation - in institutional (structures) and topical (projects, actions, etc.) aspects. ${ }^{36}$ It seems that the aforementioned proposal has a potential to fulfil these requirements. Both the general institutional framework of the new model (high-level political dialogue mechanism and high level summits in the form of an inter-governmental summit with the 28 (27) member states or a trilateral meeting of the presidents of Turkey, the Commission

33 See. e.g. Turkey 2018..., p. 96-98.

34 A. Szymański, Conclusion, [in:] Turkey and Europe. Challenges and opportunities, ed. A. Szymański, Polski Instytut Spraw Międzynarodowych, Warsaw 2012, p. 281-290.

35 Y. Şahin, Deciphering the "positive agenda" in Turkey-EU relations, Economic Development Foundation, December 2012 (IKV Brief, 16), available at: <https://oldweb.ikv.org. tr/images/upload/data/files/ikv_brief16_positive_agenda.pdf $>$ [accessed: 21 VI 2019].

A. Szymański, Conclusion..., p. 282-285. 
and the Council of the EU $)^{37}$ and concrete (necessary) structures within the CFSP to which Turkey could be included (PESCO, EDA, different bodies within the Foreign Affairs Council - from a working group to ministerial level) may serve as the sufficient forum for definition of interests, priorities and expectations, apart from updating on the foreign policy activities of both sides..$^{38} \mathrm{This}$ has a lot to do with one condition of the development of international cooperation the international regime which reduces the information and transactional costs.

When it comes to the expectations, they can be clearly met with the implementation of the new formula of the EU-Turkey relations, particularly on the Turkish side (which was previously the main obstacle for the cooperation with the EU within the foreign policy). Turkey was ready to discuss the EU proposals which could give Turkey something more than it already had in relations with the EU - both with reference to the general formula of relations as well as cooperation in a particular field, including the foreign policy. This concerns also the idea of differentiated integration for EU-Turkey relations, which was not outright rejected by Turkish politicians. For instance, the former Minister for the EU Affairs Eğemen Bağış claimed that the new model must just give Turkey something more in economic, political and legal terms (such added value was missing in the previous alternative concepts). ${ }^{39}$

The proposal of further inclusion of Turkey in the CFSP within the model of differentiated integration meets the Turkish expectations in this context. Turkey wanted to have a genuine influence on decision-making processes and on the implementation of individual projects within the CFSP, to be consulted on important foreign affairs issues and develop dialogue with CFSP/ESDP (now CSDP) bodies, take part in ESDP (now CSDP) planning (e.g. through informal policy planning talks) and missions in Turkey's neighbourhood (while it was e.g. barred from participation in missions in Georgia and Iraq)..$^{40}$ The proposal of further inclusion of Turkey in the CFSP within the new model of the EU-Turkey relations covers these issues, although in the case of its acceptance it would be still problematic to meet the Turkish expectations concerning ESDP (now CSDP) - due to the Cyprus veto. Concrete projects that

37 S. Erkuş, EU choosing to "re-engage" with Turkey. Official, "Hurriyet Daily News" [online], 12 VI 2017 [accessed: 21 VI 2019], available at: <http://www.hurriyetdailynews. com/eu-choosing-to-re-engage-with-turkey-official-.aspx?PageID $=238 \& \mathrm{NID}=114201 \& \mathrm{~N}$ ewsCatID $=510>$.

38 Adam Szymański's interview with Almut Möller, European Council on Foreign Relations (ECFR), Berlin, 21 IX 2016, .

39 C. Karakaş, EU-Turkey..., p. 1067.

40 A. Szymański, Conclusion..., p. 283-284. 
could be offered to Turkey after the inclusion in the CFSP are e.g. PESCO projects (particularly without the participation of Cyprus whose military potential is limited ${ }^{41}$ ), if Turkey joins this Treaty-based framework.

\section{Critical points}

However, some obstacles may appear on the way to the smooth inclusion of Turkey in the CFSP and the development of foreign policy cooperation with the EU countries, having much to do with perceptions and interests in this field of the EU institutions, member states and Turkey itself.

When it comes to the European Commission, its position towards the implementation of the aforementioned model should be fairly positive as the increasing participation of Turkey in the CFSP was a substantial part of the Commission's Positive Agenda. However, this old initiative and the new model of the differentiated integration for the EU-Turkey relations differ in terms of the scope of changes in the institutional framework of the enlargement policy. In the case of foreign and security field it means first of all giving some decision-making (or at least decision-shaping) rights, belonging so far to the member states. The path dependence and resistance of EU institutions to policy change could prevent embracing a model that is going too far beyond the current enlargement policy. ${ }^{42}$ The Commission can be cautious about including Turkey in the EU decision-making process for fear of blurring the boundary between a member and non-member. Moreover, this institution can also insist on keeping intact the mechanism of conditionality. ${ }^{43}$ It would mean the Commission's proposal of some specific criteria (benchmarks) of inclusion of Turkey in particular parts of the CFSP, whose fulfilment by this state could be difficult. It will be more than certain if it embraces the current Copenhagen political criteria, which can be perceived by Turkey as being against its interest - such as normalization of relations with neighbours, also in the case of some EU members, e.g. Cyprus or Greece.

As far as the EU member states are concerned, Turkey may be important for them in the field of foreign and security policy, but this may not be enough for some of them to accept all detailed arrangements of the Turkish

41 S. Aydın-Düzgit, PESCO and third countries. Breaking the deadlock in European security, University of Cologne, January 2017 (FEUTURE Voices, 3), p. 2-3, available at: $<$ http://www.feuture.uni-koeln.de/sites/feuture/pdf/FEUTURE_Voice_No_3_S._AydinDuezgit.pdf $>$ [accessed: 21 VI 2019].

42 P. Pierson, The path to European integration. A historical institutionalist analysis, "Comparative Political Studies" 1996, vol. 29, No. 2, p. 123-163.

43 B. Lippert, The nexus..., p. 8ff. 
inclusion in the CFSP. The problems of cooperation with 28 (27) states with divergent interests - regarding particularly common neighbouring regions such as the Middle East, South Caucasus or Western Balkans (including diverse attention paid to these regions by individual member states as well as contradictory interests of these countries and Turkey within the regions) and the question of their sufficient gains to agree to the cooperation (mentioned within the conditions of development of international cooperation) are clear in this context. On the one hand, the real fears of the change in balance of power in the CFSP (due to inclusion of Turkey in the decision-making process), different approach to regional affairs and conflicts and too much non-Western (now Russian) influence on the common defence initiatives, can prevail over having Turkey on the CFSP board. On the other hand - increased politicization of the EU-Turkey relations can easily result in a deadlock concerning the inclusion of Turkey in the CFSP. Key issues are: (1) how exactly Turkey will be integrated into decision-making (or at least shaping) within the CFSP and (2) how member states will decide whether inclusion criteria (benchmarks) have been fulfilled. If unanimity is required, we may expect a blockage by a single country. For example, Turkish membership in EDA or some PESCO projects could be single-handedly blocked by Cyprus due to its particular security concerns in relation to Turkey.

However, what is most debatable in relation to the smooth inclusion of Turkey into the CFSP within the new possible model of relations and the development of cooperation within this policy with reference to common neighbours may be Turkey itself and its current approach to foreign policy. Although the general approach of the EU states and Turkey to the Middle East or South Caucasus has been still similar - i.e. they all want to manage the existing instability and prevent further destabilization as well as development of security threats ${ }^{44}$, there is a divergence of positions and interests concerning e.g. relations with each country in these regions. However, this is not the main obstacle to the inclusion of Turkey in the CFSP and cooperation within this policy - this divergence is also seen among EU member states. A growing difference between foreign and security policy culture (strategic culture) of Turkey and EU members is much more debatable.

In the first decade of the $21^{\text {st }}$ century we could observe the process of Europeanization of the Turkish policy - connected with the pre-accession

44 T. Dokos, Turkey and European security, [in:] Turkey's accession to the European Union, ed. C. Arvanitopoulos, Springer, Berlin-Heidelberg 2009, p. 77-79. 
process. ${ }^{45}$ It was related to a gradual transformation of foreign and security policy culture of Turkey - in general terms to the change from focusing on the importance of military security and balance-of-power politics to the increasing appreciation of the value of civilian instruments of law, economics and diplomacy as well as multilateral international structures. ${ }^{46}$ Some of them associated the change with the Justice and Development Party (Adalet ve Kalkinma Partisi, AKP) ruling and implementation of the strategic depth doctrine of Ahmet Davutoğlu ${ }^{47}$, although the change began actually before 2002. Turkey started pursuing a pro-active policy, with the extensive use of soft power tools and decreasing securitization, paying attention to good relations with neighbours and contributing to the stabilization of neighbouring regions. ${ }^{48}$ These changes made Turkey closer to the European standards (goals) of foreign policy and post-modern approach to security with emphasis on soft-power tools.

It did not change much when the phenomenon of soft Eurasianism ${ }^{49}$ appeared in the Turkish foreign policy at the end of the first decade of the $21^{\text {st }}$ century (due to more emphasis on other vectors of foreign policy than the Western axis) because the process of soft Europeanization was still on track. However, after the events of the Arab Spring the Turkish foreign and security policy culture departed substantially from the European standards. It was reflected by the reference to the neighbouring regions, particularly the Middle East. Some components of the old model of the Turkish foreign policy have come back, i.e. the securitization of the foreign policy (democracy promotion came to the background due to the domestic situation) and more extensive use of the hard power tools (of course, without resigning from the variety of soft power instruments).

Simultaneously, some other mutually reinforcing and interconnected elements have become components of the foreign and regional (mainly Middle Eastern) policy of Turkey - in many cases inconsistent with the European foreign and security policy culture. First of all, it is the policy with the substantial

45 See e.g. Ö. Terzi, The influence of the European Union on Turkish foreign policy, Routledge, London 2010.

46 M. Emerson, N. Tocci, Turkey as a bridgehead..., p. 33.

47 A. Murinson, The strategic depth doctrine of Turkish foreign policy, "Middle Eastern Studies" 2006, vol. 42, No. 6, p. 945-964.

48 Z. Öniş, Turkey and the Middle East after September 11. The importance of the EU dimension, "Turkish Policy Quarterly" 2003, No. 4, p. 1-9.

49 Z. Öniş, Ş. Yılmaz, Between Europeanization and Euro-Asianism. Foreign policy activism in Turkey during the AKP era, "Turkish Studies" 2009, vol. 10, No. 1, p. 7-24. 
influence of domestic politics that leads to the lack of strategic, long term thinking in foreign policy. ${ }^{50}$ The Turkish policy towards Syria is the best example, where the Kurdish issue on national level, national security policy as well as thinking about the support of nationalist electorate determine Turkey's actions, including military operations in Syria. This is not something special for Turkey. However, in the Turkish case, it calls into question its ability to coordinate the external actions with the EU partners and be part of long-term initiatives (such as the EU regional strategies). Moreover, the impact of domestic politics on foreign policy of Turkey goes hand in hand with the influence and instrumental use of the religious and ideological factors, being far from rather secular characteristics of the EU states' foreign policy. This leads to frequent support for the certain, often Sunni groups in different countries, e.g. in Iraq and Syria or particular Islamist political forces - Muslim Brotherhood in Egypt among others and excludes (due to lack of impartiality) the possibility of playing a role of facilitator of contacts between parts of regional conflicts. It was the Turkish asset in the first decade of the $21^{\text {st }}$ century - highly valued by the EU partners. ${ }^{51}$ The ideologisation of the Turkish foreign policy is reflected also in the impact (use) of nationalism determining not only particular external activities of Turkey but also its military industry. It can be difficult for Turkey to be part of some defence projects within PESCO if the Turkish domestic manufacturing of weaponry (in addition to cooperation with such countries as Russia or China) prevails over international undertakings in the Euroatlantic realm. ${ }^{52}$

When it comes to the actors of the Turkish foreign policy, the process of personalization takes place, with a limited number of persons having impact on the decision making process in this field and with the special position of President Recep Tayyip Erdoğan. ${ }^{53}$ It can facilitate contacts with countries with a similar decision-making system such as Russia but not necessarily with the EU partners.

50 W. Hale, Turkey's domestic politics, public opinion and Middle East policy, "Palgrave Communications" 2017, vol. 2 (doi:10.1057/palcomms.2016.81).

51 A. Szymański, Turkey's potential added value to the EU. Resolution of regional conflicts, "Turkish Policy Quarterly" 2009, vol. 8, No. 3, available at: <http://turkishpolicy. $\mathrm{com} /$ Files/ArticlePDF/turkeys-potential-added-value-to-the-eu-resolution-of-regional-conflicts-fall-2009-en.pdf> [accessed: 21 VI 2019].

52 A. Tekingunduz, Turkey's growing defence industry, "TRT World" [online], 4 V 2018 [accessed: 21 VI 2019], available at: <https://www.trtworld.com/turkey/turkey-s-growing-defence-industry-17014>.

53 Adam Szymański's interview with Ioannis Grigoriadis, Stiftung Wissenschaft und Politik (SWP), Berlin, 19 IX 2016. 
Generally speaking, there is not only the problem of sharing of the general model of foreign policy as well as particular rules, goals and instruments, but also of a different perception of international problems (for example terrorism) and their solution. When we take into consideration that this deficit together with the aforementioned dysfunctional impact of Turkish domestic politics generate problems for international reputation of Turkey and trust in this country (other conditions of smooth international cooperation), the prospects of advanced cooperation between the EU and Turkey within the CFSP are vague.

\section{Conclusions}

The aim of the article was to analyse the possibility of further inclusion of Turkey into the CFSP of the EU and the development of cooperation in this field, particularly in the common neighbourhood - within the new extended model of the differentiated integration. Assuming that the EU members states give the model a green light in general terms, the key question is if it can be effectively implemented in the field foreign and security policy, i.e. if Turkey can participate in the bodies, projects and decision-making (or, more realistically, decision-shaping) process within the CFSP - according to the proposals presented by the aforementioned scholars.

There are promising factors in this context such as the mutual interests in the development of cooperation in the neighbourhood to face common challenges as well as the solid basis for further inclusion of Turkey in the CFSP and prospects for removing the previous obstacles for smooth foreign policy cooperation between the EU and the Turkish partner - thanks to the structural and topical parts of the new model. It means fulfilment of some key conditions of development of international cooperation - i.e. relative gains on both sides and assets of being together part of a kind of international regime.

However, at the same time, the article positively verifies the hypothesis that the further inclusion of Turkey in the CFSP and the development of cooperation in this field between the EU members and Turkey eventually depend on preferences and interests in this field of major actors, namely European Commission, EU members states and Turkey itself. It is currently highly questionable, particularly when we take into account all important conditions of the development of the international cooperation.

The European Commission and the EU member states can insist - taking into consideration their other interests and gains than the ones connected with participation of Turkey in the CFSP - on a moderate and incremental 
inclusion - first of all in the decision making process in the foreign and security policy but also in particular structures and projects within the CFSP. It can be rejected by Turkey as suboptimal and unsatisfactory - from the point of view of its relative gains. The EU member states having strained relations with Turkey may even effectively block the whole undertaking if the inclusion of Turkey into particular parts of the CFSP requires the unanimity. The optimal option for this country can be then the cooperation mainly within NATO particularly in the situation of the lack of substantial asymmetry between the Turkish state and the EU, required for the cooperation agreement.

However, from the point of view of conditions of international cooperation and current political determinants particularly problematic can be the divergence of the foreign and security culture between Turkey and the EU members. The domestication, personalisation and ideologisation of the Turkish foreign and regional (especially Middle Eastern) policy seem to be crucial obstacles for cooperation within the CFSP and participation of Turkey in the undertakings within this area of EU activities.

\section{Bibliography}

Atilgan C., Klein D., EU integration models beyond full membership, Konrad Adenauer Stiftung, Berlin 2006 (Working Paper, 158), available at: <http://www.kas.de/wf/doc/ kas_8414-544-2-30.pdf?061221153540> [accessed: 21 VI 2019].

Aydın-Düzgit S., PESCO and third countries. Breaking the deadlock in European security, University of Cologne, January 2017 (FEUTURE Voices, 3), available at: <http://www. feuture.uni-koeln.de/sites/feuture/pdf/FEUTURE_Voice_No_3_S._Aydin-Duezgit.pdf> [accessed: 21 VI 2019].

Aydın-Düzgit S., Tocci N., Turkey and the European Union, Palgrave Macmillan, LondonNew York 2015.

Barigazzi J., Doors open to keep Britain in EU (security), "Politico" [online], 5 V 2018 [accessed: 21 VI 2019], available at: $<$ https://www.politico.eu/article/europe-defense-pescomilitary-extend-cooperation-to-non-eu-countries-say-benelux-countries $>$.

Cianciara A.K., Differentiated integration in the European Union and its prospects in the context of enlargement and neighbourhood policies, [in:] The Euro-Atlantic system in a multi-polar world. A forecast, ed. J.M. Fiszer et al., Logos, Berlin 2015.

Cianciara A.K., Szymański A., Differentiated integration. Towards a new model of European Union-Turkey relations?, "Turkish Studies” [online], 22 V 2019 [accessed: 21 VI 2019], available at: $<$ https://doi.org/10.1080/14683849.2019.1618190>.

Dai X., Snidal D., Sampson M., International cooperation theory and international institutions, [in:] Oxford research encyclopedia of international studies, Oxford University Press, Oxford, March 2010.

Dokos T., Turkey and European security, [in:] Turkey's accession to the European Union, ed. C. Arvanitopoulos, Springer, Berlin-Heidelberg 2009. 
Emerson M., Tocci N., Turkey as a bridgehead and spearhead. Integrating EU and Turkish foreign policy, Centre for European Policy Studies, August 2004 (EU-Turkey Working Papers, 1).

Erkuş S., EU choosing to "re-engage” with Turkey. Official, "Hurriyet Daily News" [online], 12 VI 2017 [accessed: 21 VI 2019], available at: <http://www.hurriyetdailynews.com/ eu-choosing-to-re-engage-with-turkey-official-.aspx?PageID $=238 \& \mathrm{NID}=114201 \& \mathrm{New}$ $\mathrm{sCatID}=510>$.

The Euro-Atlantic system in a multi-polar world. A forecast, ed. J.M. Fiszer et al., Logos, Berlin 2015.

Gstöhl S., Models of external differentiation in the EU's neighbourhood. An expanding economic community?, "Journal of European Public Policy” 2015, vol. 22, No. 6.

Güsten S., Salzen C. von, Fall Yücel hat für uns besondere Dringlichkeit. "Der Tagesspiegel” [online], 16 II 2018 [accessed: 21 VI 2019], available at: <https://www.tagesspiegel.de/ politik/-deutschland-und-die-tuerkei-fall-yuecel-hat-fuer-uns-besondere-dringlichkeit/ 20968418.html>.

Guttenberg K.-T. zu, Die Beziehungen zwischen der Türkei und der EU-eine "Privilegierte Partnerschaft", Hanns-Seidel-Stiftung, Akademie für Politik und Zeitgeschehen, München 2004 (Aktuelle Analysen, 33), available at: <https://www.hss.de/fileadmin/migration/ downloads/aa33_internet.pdf $>$ [accessed: 21 VI 2019].

Hale W., Turkey's domestic politics, public opinion and Middle East policy, "Palgrave Communications" 2017, vol. 2 (doi:10.1057/palcomms.2016.81).

Karakaş C., EU-Turkey. Integration without full membership or membership without full integration? A conceptual framework for accession alternatives, "Journal of Common Market Studies" 2013, vol. 51, No. 6.

Karakas C., Gradual integration. An attractive alternative integration process for Turkey and the EU, "European Foreign Affairs Review" 2006, vol. 11, No. 3.

Kirişci K., Bülbül O., The EU and Turkey need each other. Could upgrading the customs union be the key?, "Brookings" [online], 29 VIII 2017 [accessed: 21 VI 2019], available at: $<$ https://www.brookings.edu/blog/order-from-chaos/2017/08/29/the-eu-and-turkey-need-each-other-could-upgrading-the-customs-union-be-the-key>.

Lavenex S., Concentric circles or flexible 'EUropean'Integration. A typology of EU external governance relations, "Comparative European Politics" 2011, vol. 9, No. 4-5.

Lippert B., The nexus between enlargement and differentiation, Instituto Affari Internazionali, [Roma] 7 II 2017, available at: <http:/www.iai.it/sites/default/files/eu60_2.pdf $>$ [accessed: 21 VI 2019].

Martill B., Sus M., Post-Brexit EU/UK security cooperation: NATO, CSDP+, or "French connection”?, "The British Journal of Politics and International Relations" 2018, vol. 20, No. 4.

Milner H., International theories of cooperation among nations. Strengths and weaknesses, "World Politics" 1992, vol. 44, No. 3.

Müftüler-Baç M., Turkey's future with the European Union. Alternative model of differentiated integration, "Turkish Studies" 2017, vol. 18, No. 3.

Müftüler-Baç M., Luetgert B., The European Union's alternative models for maximizing its integration strategy for candidates and neighbour states. A process of external differentiation, [Berlin] November 2016 (MAXCAP Working Paper, 35), available at: <http://userpage.fu-berlin.de/kfgeu/maxcap/system/files/maxcap_wp_35.pdf $>$ [accessed: 21 VI 2019]. 
Murinson A., The strategic depth doctrine of Turkish foreign policy, "Middle Eastern Studies" 2006, vol. 42, No. 6 .

Öniş Z., Turkey and the Middle East after September 11. The importance of the EU dimension, "Turkish Policy Quarterly" 2003, No. 4.

Öniş Z., Y1lmaz Ş., Between Europeanization and Euro-Asianism. Foreign policy activism in Turkey during the AKP era, "Turkish Studies" 2009, vol. 10, No. 1.

Özcan C., Merkel conveys Germany's veto on Customs Union update with Turkey to Juncker, "Hurriyet Daily News" [online], 31 VIII 2017 [accessed: 21 VI 2019], available at: <http:// www.hurriyetdailynews.com/merkel-conveys-germanys-veto-on-customs-union-updatewith-turkey-to-juncker-117422>.

Permanent Structured Cooperation - PESCO, 5 III 2018, available at: $<$ https://eeas.europa.eu/ sites/eeas/files/pesco_factsheet_09-03-2018_0.pdf>.

Pierson P., The path to European integration. A historical institutionalist analysis, "Comparative Political Studies" 1996, vol. 29, No. 2.

Pisani-Ferry J., Röttgen N., SapirA., TuckerP., WolffG.B., Europe after Brexit. A proposal for a continental partnership, "Bruegel" [online], 29 VIII 2016 [accessed: 21 VI 2019], available at: $<$ http://bruegel.org/2016/08/europe-after-brexit-a-proposal-for-a-continental-partnership>.

Positive EU-Turkey agenda launched in Ankara, Brussels, 17 V 2012, available at: $<$ http://europa.eu/rapid/press-release_MEMO-12-359_en.htm> [accessed: 21 VI 2019].

President Jean-Claude Juncker's state of the Union address 2017, "European Commission" [online], 13 IX 2017 [accessed: 21 VI 2019], available at: <http://europa.eu/rapid/ press-release_SPEECH-17-3165_en.htm>.

Quaisser W., Wood S., EU member Turkey? Preconditions, consequences and integration alternatives, Forost, [München] October 2004 (Forost Arbeitspapier, 25), available at: $<$ http://edoc.vifapol.de/opus/volltexte/2008/806/pdf/forost_Arbeitspapier_25.pdf $>$ [accessed: 21 VI 2019].

Şahin Y., Deciphering the "positive agenda" in Turkey-EU relations, Economic Development Foundation, December 2012 (IKV Brief, 16), available at: <https://oldweb.ikv.org.tr/images/upload/data/files/ikv_brief16_positive_agenda.pdf $>$ [accessed: 21 VI 2019].

Szymański A., Alternatives to EU membership. The case of Turkey, "The Polish Quarterly of International Affairs" 2007, No. 4.

Szymański A., Conclusion, [in:] Turkey and Europe. Challenges and opportunities, ed. A. Szymański, Polski Instytut Spraw Międzynarodowych, Warsaw 2012.

Szymański A., Turkey's potential added value to the EU. Resolution of regional conflicts, "Turkish Policy Quarterly" 2009, vol. 8, No. 3, available at: <http://turkishpolicy.com/Files/ ArticlePDF/turkeys-potential-added-value-to-the-eu-resolution-of-regional-conflicts-fall2009-en.pdf> [accessed: 21 VI 2019].

Tekingunduz A., Turkey's growing defence industry, "TRT World” [online], 4 V 2018 [accessed: 21 VI 2019], available at: <https://www.trtworld.com/turkey/turkey-s-growing-defence-industry-17014>.

Terzi Ö., The influence of the European Union on Turkish foreign policy, Routledge, London 2010.

Turhan E., Thinking out of the accession box. The potential and limitations of internal and external differentiated integration between Turkey and the EU, Centre international de formation européenne, 3 VII 2017 (CIFE Policy Paper, 58), available at: <https://www.cife.eu/ 
Ressources/FCK/files/publications/policy\%20paper/CIFE_Policy_Paper_58_Thinking_out_ of_The_Accession_Box_EU_Turkey_Ebru_Turhan_2017_1.pdf $>$ [accessed: 21 VI 2019].

Turkey 2018 Report. Strasbourg, 18 IV 2018, SWD(2018) 153 final, available at: <https:// ec.europa.eu/neighbourhood-enlargement/sites/near/files/20180417-turkey-report.pdf> [accessed: 21 VI 2019].

Turkey and Europe. Challenges and opportunities, ed. A. Szymański, Polski Instytut Spraw Międzynarodowych, Warsaw 2012.

Turkey's accession to the European Union, ed. C. Arvanitopoulos, Springer, Berlin-Heidelberg 2009.

Ülgen S., Avoiding a divorce. A virtual EU membership for Turkey, "Carnegie Europe" [online], 5 XII 2012 [accessed: 21 VI 2019], available at: <http://carnegieeurope.eu/2012/12/05/ avoiding-divorce-virtual-eu-membership-for-turkey-pub-50218>. 